\title{
The Effects of Brand Management on Brand Equity in Mexican Small Firms
}

\author{
Gonzalo Maldonado-Guzmán \\ Sandra Yesenia Pinzón-Castro \\ José Trinidad Marín-Aguilar \\ Universidad Autónoma de Aguascalientes \\ Centro de Ciencias Económicas y Administrativas \\ Departamento de Mercadotecnia
}

\begin{abstract}
Brand management and brand equity are two marketing activities that have recently attracted a high level of interest from several scholars, researchers and professionals, not only because they are part of the main business strategies implemented by companies nowadays but also because these two actions create several competitive advantages in the organizations, especially in small firms. Nonetheless, despite the importance of these activities, there are few published investigations in the marketing literature that have analyzed and discussed them together. There are even less the researches focused on small firms. Thus, the main objective of this empirical research is the analysis and discussion of the effects of brand management in the brand equity of small firms by using a sample of 300 small enterprises and by implementing a model of structural equations that allows a deeper understanding of the current relation between brand management and brand equity. The results obtained show that brand management has a positive and significant effect in the level of brand equity of small firms.
\end{abstract}

Keywords: Brand, brand management, Brand equity, small firms.

\section{Introduction}

The current chaos in the business environment that affects big transnational enterprises and, perhaps even more, small firms is usually due to market changes, the fragmentation of the distribution and the increasing importance of the creation of value among companies and their consumers (M'zunguet al., 2010). Consequently, the creation of value, as an intangible resource of the organization, plays an essential role in the differentiation of enterprises from their main competitors as well as in the production of competitive advantages which, among the most important ones, include organizational advantages, competences, skills, the creation of new knowledge and, evidently, the strengthening of the brand (M'zunguet al., 2010).

In this regard, there is a significant increase in the last two decades of published investigations in the marketing literature that have analyzed the importance of branding as an intangible resource of enterprises. This is evidenced by several financial reports of the main current brands in the market (M'zunguet al., 2010). For example, the brand value, in financial terms, of the main international brands of products and services represents a significant percentage of their market capitalization, as it is the case of Coca-Cola whose market capitalization represents 59\%, McDonalds has a market capitalization of 64\% and BMW has a market capitalization of 77\% (Aaker \& Joachimsthaler, 2000).

Additionally, several scholars, researchers and professionals of marketing have provided theoretical and empirical evidence of the importance of brand management and brand equity as intangible resources in enterprises (Jeon, 2017). Thus, brand management usually has a strong impact in both the loyalty of the brand and the financial value of the brands of firms (Srivastavaet al., 1998; Oliver, 1999; Chaudhuri \& Holbrook, 2001). Likewise, an important part of the papers published about brand management and brand equity have focused on the evaluation about the importance of branding in the marketing strategy (Jeon, 2017), even when Aaker (1991) had already suggested to analyze the commitment of consumers in brand management and brand equity as allows enterprises to obtain several competitive advantages such as the decrease of marketing costs and appealing new consumers.

Thus, one of the main determiners of the commitment of consumers is the concept of brand management that organizations adopt and implement (Park et al., 1986; Chaudhuri \& Holbrook, 2001) because this concept will not only improve the brand image of enterprises (Park et al., 1986) but it will also create direct and indirect effects in brand equity of the products or services produces by the organization (Jeon, 2017). 
Therefore, managers of enterprises, especially small firms because this could create a higher emotional commitment with their consumers as well as a higher brand equity (Chaudhuri\& Holbrook, 2001; Brakuset al., 2009; Maläret al., 2011).

More recently some investigations have focused on the analysis of a strong brand in small firms, specifically because it reflects brand equity through emotional attachment and commitment of consumers (Morgan \& Hunt, 1994; Fournier, 1998; Oliver, 1999). However, most scholars, researchers and professionals of marketing have analyzed them in a separate way and have paid little attention in proving how brand management and produces more brand equity (M'zunguet al., 2010). Therefore, considering that there are relatively few empirical research published papers that have analyzed the relation between brand management and brand equity, the main contribution of this empirical investigation is the analysis and discussion of the effects of brand management on the brand equity of small firms just as it is recommended by M'zunguet al. (2010) as well as Jeon (2017).

\section{Literature Review}

Some theoretical and empirical research papers published in the marketing literature have established that branding refers to a name, term, sign, symbol, design (or a combination of them) that attempts to identify some specific goods or services from all the goods and services that exist in the market (Aaker, 1991; Kotler\& Armstrong, 2010). That is why branding has been considered as an essential element of marketing for decades that helps to differentiate the products or services of a specific enterprise (Jeon, 2017). More specifically, Park et al. (1986) had already suggested that the success of the brand of products or services of firms on the long term depended mostly on the correct choice of the concept of brand management that managers have for their participation in the market.

Similarly, Park et al. (1986) concluded that brand management would have to be defined in terms of the needs of consumers. More specifically, the concept of brand management is based on the development of an aesthetic, functional and symbolic brand (Park et al., 2013) which has more effects in the brand equity of goods and services. Thus, the management of an aesthetic brand is practically based on the anticipation of the satisfaction of the requirements and needs of consumers that the market demands (Jeon\& Lee, 2016). That is why the creation of aesthetic experiences of brand management has become a relevant topic of the marketing activities of organizations, especially small firms and it has increased its importance in the experiential aspects of the consumption of goods and services (Holbrook \& Hirschman, 1982).

In the context of marketing, the aesthetic needs of the brand are usually considered as the requirements of goods or services that provide consumers with a satisfaction (Jeon, 2017) because when consumers consider the quality of goods and services as a fundamental element, the aesthetics of the brand play a determining role in both the purchase intention and decision (Park et al., 1986; Park et al., 2013). For this reason, the aesthetics in brand management has normally been analyzed from a visual perspective, and it has ignored the analysis of other senses such as taste, smell and the interaction of senses which is why the experience of consumers in the aesthetics of the brand is a topic that has been omitted in the traditional marketing research (Krishna et al., 2010).

On the other hand, functional brand management emphasizes both the value and functional performance of the brand of goods and services produced by small firms since, in the market literature, the functional value of the brand is usually considered as the capacity of goods and services to carry out their functions adequately in the lives of consumers (Hirschman \& Holbrook, 1982). Therefore, the functional needs are considered by some scholars, researchers and professionals of marketing as the motivation to look for products or services that can solve the problems related to their own consumption (Park et al., 1986; Park et al., 2013).

In this regard, the functional needs are closely linked to the basic motivations of consumers about getting products or services with a higher value and functional performance (Jeon\& Lee, 2016). That is why the functional brand management will have to be designed to solve as soon as possible the needs and preferences of consumers (Chaudhuri \& Holbrook, 2001; Brakuset al., 2009). That is why Park et al. (2010) considered that brand management will have to focus not only on the decrease of uncertainty produced by goods and services in the daily life of consumers but also on meeting the results wanted by consumers through a higher control and efficiency of brand management which could create a higher brand equity.

Accordingly, symbolic brand management emphasizes the relation between the brand and the recognition of consumers and it usually reflects an important part of the identity of consumers (Jeon, 2017) since the brand has the ability to define current consumers or their interests to be different from the others (McCracken, 1990). Consequently, consumers often evaluate the prestige, exclusivity or fashion of a specific brand because they make a positive bond with it. 
This produces not only a significant improvement of the consumers' choice for decision making about purchase intention of a brand of goods or services (McCracken, 1990; Park et al., 2010) but also in the creation of a higher brand equity of such goods or services (Jeon\& Lee, 2016).

In this trend of ideas, Keller (1993) suggested that brand equity should be defined as the level of awareness and familiarity of consumers with a brand, which encourages significantly the brand management of products or services as well as the purchase intention of consumers. That is why it is possible to state that there is brand equity when the elements of brand management are in the minds of consumers (M'zunguet al., 2010). Similarly, Aaker (1992) considered that brand equity can be conceptualized in five basic components which are practically the resources of brand equity: brand loyalty, brand awareness, value perception of the brand, brand associations (or brand image) and quality perception of the products.

Regarding the brand of services, in which small firms represent usually the very brand, Berry (2000) concluded that brand management contributes significantly to the production of higher brand equity because brand management refers mostly to the dominant perception of a specific brand in consumers (M'zunguet al., 2010). Thus, according to Berry (2000), the presence of the brand in the market, the external communication of the brand the consumers experience with the brand of a specific enterprise can be considered basically as the essential sources of the perception of consumers of brand management which in turn will create a lower or higher brand equity of the goods or services of firms (M'zunguet al., 2010).

On the other hand, Feldwick (1996) and Kapferer (2004) considered that brand equity can be analyzed from three different points of view: 1) as the total value of the brand (especially when the brand is on sale or in the company's balance sheet); 2) as a measure of the strength of attachment of consumers with the brand; and 3) as a description of associations and beliefs that consumers have about the brand. Thus, the first point of view represents a financial perspective of brand equity whereas the second point of view refers practically to brand equity as the loyalty of consumers towards the brand. Finally, the third point of view considers brand equity as the image of both the brand of products and services and the very company (M'zunguet al., 2010).

In this regard, the best way to analyze brand equity is through a combination of the three points of view previously discussed, that is, through the actives of the brand (image, reputation, values and patents) which normally produce a strong brand management (market share, leadership in the market, brand loyalty, and the ability to establish a special price) which results in a significant increase of brand equity in financial terms (Kapferer, 2004). Therefore, the brand management of products and services created by small firms will have to focus on the financial value of the brand as it represents "the net cash flow attributable to the brand after paying the cost of capital invested in the production as well as marketing costs." (Kapferer, 2004: 14).

In general terms, scholars, researchers and professionals of marketing consider that there are some factors that have a strong influence in the creation of brand equity. Some of the most important ones are the strategic ideas of enterprises, the effectiveness of the implementation of business strategies and, obviously, brand management (Jeon, 2017). Consequently, it is evident that there is higher brand equity when there are good results obtained from the brand management of products and services of a specific brand in comparison to the lack of brand management (Kotler\& Armstrong, 2010). Thus, considering the information presented

\section{H1:The higher level of brand management, higher level of brand equity}

\section{Methodology}

An empirical research of small enterprises in Aguascalientes (Mexico) was carried out in order to answer the hypothesis established by using the business directory of the Sistema de Información Empresarial Mexicano 2017 (System of Mexican Business Information, or SIEM) as reference framework for Aguascalientes State which had 1,427 registered enterprises, each one containing from five to 250 workers at the end of January. Moreover, a questionnaire of data collection was designed to be answered by managers and/or owners of 300 small enterprises, which were selected through a random sampling with a maximum error of $\pm 5 \%$ and a level of reliability of $95 \%$, which represents slightly over $21 \%$ of all the small firms registered. Such interviews took place between February and April 2017.

Moreover, a scale developed by Baumgarth (2010) was used for the measurement of brand management. The researcher considered that brand management can be measured through four dimensions: Value, which was measured through a five-item scale; Norms, which were measured through a six-item scale; Artifacts, which were measured through a four-item scale; and Behaviors, which were measured through a four-item scale. Also, in order to measure brand equity, a scale adapted by Berthonet al. (2008) was taken from the scale developed by Keller (2008) who considered that brand equity can be measured through a scale of five items. 
All the items of the scales of brand management were measured through a Likert-type scale of five positions from " $1=$ completely disagree" to " $5=$ completely agree" as limits.

Similarly, a Confirmatory Factorial Analysis (CFA) was carried out to evaluate the reliability and validity of the scales of brand management and brand equity by using the method of maximum likelihood with the software EQS 6.2 (Bentler, 2005; Brown, 2006; Byrne, 2006). Thus, the reliability was evaluated with Cronbach's alpha as well as the Composite Reliability Index (CRI) (Bagozzi \& Yi, 1988). The results obtained from the CFA are shown in Table 1, and show that the theoretical model analyzed has a good adjustment of data $\left(S-B X^{2}=1,404.589 ; d f=241 ; p=0.000 ; N F I=\right.$ $0.856 ; N N F I=0.860 ; C F I=0.877 ; R M S E A=0.079)$. Likewise, the values of Cronbach's alpha and the CRI are higher than 0.7 , which indicates the presence or reliability in the scales of brand management and brand equity (Nunally \& Bernstein, 1994; Hair et al., 1995).

Accordingly, the results obtained from the CFA indicate that all the items of the factors related are significant ( $\mathrm{p}<$ 0.01). The value of all the standardized factorial loads is higher than 0.6 (Bagozzi \& Yi, 1988) and the Extracted Variance Index (EVI) of each pair of constructs of the theoretical model of brand management and brand equity has a value over 0.5 (Fornell \& Larcker, 1981). These values indicate that the theoretical model has an excellent adjustment of data and provide evidence of the presence of convergent validity.

Table 1. Internal consistency and convergent validity of the theoretical model

\begin{tabular}{|c|c|c|c|c|c|c|}
\hline Variable & Indicator & $\begin{array}{l}\text { Factorial } \\
\text { Loading }\end{array}$ & \begin{tabular}{|c|} 
Robust t- \\
Value
\end{tabular} & $\begin{array}{c}\text { Cronbach's } \\
\text { Alpha }\end{array}$ & CRI & EVI \\
\hline \multirow{5}{*}{$\begin{array}{l}\text { Value } \\
\text { (F1) }\end{array}$} & VM1 & $0.968 * * *$ & $1.000^{\mathrm{a}}$ & \multirow{5}{*}{0.978} & \multirow{5}{*}{0.979} & \multirow{5}{*}{0.902} \\
\hline & VM2 & $0.972 * * *$ & 78.349 & & & \\
\hline & VM3 & $0.959 * * *$ & 46.339 & & & \\
\hline & VM4 & $0.939 * * *$ & 36.679 & & & \\
\hline & VM5 & $0.908 * * *$ & 29.432 & & & \\
\hline \multirow{6}{*}{$\begin{array}{l}\text { Norms } \\
\text { (F2) }\end{array}$} & NM1 & $0.881 * * *$ & $1.000^{\mathrm{a}}$ & \multirow{6}{*}{0.928} & \multirow{6}{*}{0.929} & \multirow{6}{*}{0.686} \\
\hline & NM2 & $0.855 * * *$ & 32.927 & & & \\
\hline & NM3 & $0.867 * * *$ & 23.302 & & & \\
\hline & NM4 & $0.836 * * *$ & 20.286 & & & \\
\hline & NM5 & $0.776 * * *$ & 19.074 & & & \\
\hline & NM6 & $0.746 * * *$ & 17.439 & & & \\
\hline \multirow{4}{*}{$\begin{array}{l}\text { Artifacts } \\
\text { (F3) }\end{array}$} & AM1 & $0.966 * * *$ & $1.000^{\mathrm{a}}$ & \multirow{4}{*}{0.984} & \multirow{4}{*}{0.985} & \multirow{4}{*}{0.943} \\
\hline & AM2 & $0.974 * * *$ & 74.565 & & & \\
\hline & AM3 & $0.978 * * *$ & 51.791 & & & \\
\hline & AM4 & $0.967 * * *$ & 44.149 & & & \\
\hline \multirow{4}{*}{$\begin{array}{l}\text { Behaviors } \\
\text { (F4) }\end{array}$} & CM1 & $0.953 * * *$ & $1.000^{\mathrm{a}}$ & \multirow{4}{*}{0.942} & \multirow{4}{*}{0.943} & \multirow{4}{*}{0.807} \\
\hline & $\mathrm{CM} 2$ & $0.930 * * *$ & 37.263 & & & \\
\hline & CM3 & $0.891 * * *$ & 29.957 & & & \\
\hline & CM4 & $0.812 * * *$ & 22.431 & & & \\
\hline \multirow{4}{*}{ Brand Management } & F1 & $0.776 * * *$ & 16.839 & \multirow{4}{*}{0.893} & \multirow{4}{*}{0.894} & \multirow{4}{*}{0.680} \\
\hline & F2 & $0.828 * * *$ & 15.693 & & & \\
\hline & F3 & $0.791 * * *$ & 13.942 & & & \\
\hline & F4 & $0.898 * * *$ & 14.962 & & & \\
\hline \multirow{5}{*}{ Brand Equity } & BEQ1 & $0.844 * * *$ & $1.000^{\mathrm{a}}$ & \multirow{5}{*}{0.896} & \multirow{5}{*}{0.897} & \multirow{5}{*}{0.637} \\
\hline & BEQ2 & $0.863 * * *$ & 22.222 & & & \\
\hline & BEQ3 & $0.833 * * *$ & 18.291 & & & \\
\hline & BEQ4 & $0.739 * * *$ & 15.810 & & & \\
\hline & BEQ5 & $0.700 * * *$ & 15.754 & & & \\
\hline$S-B X^{2}(\mathrm{df}=241)=1$, & $589 ; p<0$ & $0 ; \mathrm{NFI}=0$ & $56 ;$ NNFI & $.860 ; \mathrm{CFI}=$ & 7 ; RN & $=0.079$ \\
\hline
\end{tabular}

Additionally, the discriminant validity of the theoretical model of brand management and brand equity was measured through two tests, which are shown in Table 2. Firstly, the reliability interval test (Anderson and Gerbing, 1988) which establishes that with an interval of $95 \%$ of reliability none of the individual elements of the latent factors of the matrix of correlation must have a value of 1.0. Secondly, the test of extracted variance which establishes that the extractedvariance of each pair of constructs is lower than their corresponding EVI. 
Therefore, based on the results obtained from the tests applied, it can be concluded that there is enough evidence of the presence of discriminant validity.

Table 2. Discriminant validity of the theoretical model

\begin{tabular}{|c|c|c|}
\hline Variables & Brand Management & Brand Equity \\
\hline Brand Management & $\mathbf{0 . 6 8 0}$ & 0.182 \\
\hline Brand Equity & $0.293-0.561$ & $\mathbf{0 . 6 3 7}$ \\
\hline
\end{tabular}

The diagonal represents the Extracted Variance Index (EVI), whereas above the diagonal the variance is presented (squared correlation). Below diagonal, the estimated correlation of factors is presented with $95 \%$ confidence interval.

\section{Results}

In order to answer the research hypothesis established in this empirical research, a model of structural equations was applied with software EQS 6.2 (Bentler, 2005; Byrne, 2006; Brown, 2006). Furthermore, the nomological validity of the theoretical model of brand management and brand equity was examined through the Chi-square test, which compared the results obtained between the theoretical model and the measurement model. Such results indicate that the differences between both models are not significant which can offer an explanation of the relationships observed among the latent constructs (Anderson \& Gerbing, 1988; Hatcher, 1994). Table 3 shows the results in a more detailed way regarding the implementation of the model of structural equations.

Table 3. Results of the structural equation model of second order

\begin{tabular}{|c|c|c|c|}
\hline Hypothesis & Structural Relationship & $\begin{array}{l}\text { Standardized } \\
\text { Coefficient }\end{array}$ & $\begin{array}{l}\text { Robust t- } \\
\text { Value }\end{array}$ \\
\hline $\begin{array}{l}\text { H1: The higher level of brand } \\
\text { management, higher level of brand equity. }\end{array}$ & Brand M. $\rightarrow$ Brand Equity & $0.521 * * *$ & 13.149 \\
\hline \multicolumn{4}{|c|}{$S-B X^{2}(\mathrm{df}=236)=1,263.566 ; \mathrm{p}<0.000 ; \mathrm{NFI}=0.871 ; \mathrm{NNFI}=0.873 ; \mathrm{CFI}=0.892 ; \mathrm{RMSEA}=0.079$} \\
\hline
\end{tabular}

Table 3 shows the results obtained from the implementation of the structural equations model and it can be observed that, regarding the outcomes of the research hypothesis $\mathbf{H}_{1}$, the results obtained $(\beta=0.521, p<0.01)$ indicate that brand management has significant, positive effects in the brand equity of products or services developed by small firms. Therefore, it is possible to establish that the adoption and implementation of brand management activities carried out by small firms will affect in a positive way the evaluation and perception of the brand equity made by clients and consumers of such products or services.

\section{Conclusions and Discussion}

The results obtained in this empirical research allow us to conclude in two main aspects. On one hand, there is a lot of pressure from the market so small firms manage more efficiently the brand of their products or services since the globalization of economy and markets is creating a high level of business competition. Therefore, it is possible to conclude that, in order to compete with the brands of big international companies, it is necessary that small firms focus their business strategies on the adoption and implementation of brand management activities, otherwise it will be too difficult for small enterprises to keep their current market position as well as to survive in a difficult business environment.

On the other hand, the perception of brand equity of consumers about the products or services produced by small firms is becoming in a fundamental activity for organization, specifically for small enterprises. This allows them not only to increase significantly the purchase intention of the brand of their products or services from clients and customers but companies can also increase the preference of the brand of their products or services in comparison to those offered by their main competitors. 
As a result of this, it is possible to conclude that the brand equity of the products or services developed by small firms will determine in a high percentage both the continuity of small companies in the markets where they participate and their very survival.

In this regard, it is possible to conclude in general terms that small firms have to adopt and implement the activities that need the brand management of their products or services in an efficient and effective way because this will allow them to continue in the market where they participate as well as to increase significantly the perception of brand equity of their products or services. Consequently, if one of the main goals of small enterprise is to increase the brand equity of their products or services, then, in order to achieve this objective, small firms will have to improve significantly the brand management, as this will facilitate the attainment of a higher level of perception of brand equity from consumers. Otherwise, the very survival of the organization will be at risk.

Likewise, these results also have some implications that are equally important to establish. The first one is that usually a high percentage of small firms located in developing countries and with an emerging economy, as it is the case of Mexico, do not have a registration of the trademark of the products or services they create or even the trademark of the company itself and, consequently, they do not have the rights of the intellectual property of their commercial brands. This creates serious difficulties in the attainment of a correct an efficient brand management mostly because the brand management practices and the brand itself of the products or services of small firms are too similar among them and they are usually copied or duplicated by their main competitors.

A second implication obtained from these results is that managers of small firms tend to redirect their brand management activities to the implementation of modifications or improvements required by the market of their products or services as well as their customization to the needs and preferences of their consumers. This will allow them to create a higher level of perception of brand equity of their products or services from clients and customers as well as a differentiation of their products or services in comparison to those offered by their main competitors. This could turn into a significant increase in the purchase intention and the preference of the brand of the products or services created by small firms.

A third implication of these results is that executives of small firms have to consider the different activities that imply brand management as part of their daily business activities and not only as another business strategy in the organization. This will facilitate the adoption and implementation of this type of activities into the organization. Moreover, a fourth implication of the results obtained is that executives of small firms also have to integrate all the employees and workers in the brand management activities and brand equity activities. This will promote teamwork not only to contribute with ideas for the improvement of products or services according to the needs of consumers but also to enhance brand management activities.

A fifth implication of these results is that executives of small firms have to involve all the departments or functional areas of the organization to adopt and implement brand management activities in since they do not belong to a single department but it rather demands the interaction of all the functional areas of the enterprise. Finally, a sixth implication of these results is that executives of small firms have to implement the necessary training programs for all the staff, especially in the area of brand management in order to achieve more and better competitive advantages for the organization as well as to continue and survive in the market in which they participate.

Additionally, this empirical research also has some limitations that are necessary to establish. The first one is about the sample used as only small firms that had between five and 250 workers were considered. That is why future investigations could consider in the sample small service firms with less than five workers in order to confirm the results obtained. The second limitation is that the questionnaire applied to collect the data only considered small firms in the state of Aguascalientes (Mexico). Future researches will need to apply the same questionnaire in other states of the country in order to verify the results obtained.

A third limitation is that only qualitative variables were considered to measure brand management and brand equity so in future investigations it would be relevant to use quantitative variables or hard data to prove the presence or lack of similar results Finally, a fourth limitation is that the instrument applied to collect data only considered managers and/or owners of small firms. This created the assumption in the research paper that they have a deep understanding of the different activities that imply the brand management and brand equity in their enterprises. Future research papers could consider to apply the same questionnaire to the company staff as well as their business partners in order to confirm or deny the results obtained. 


\section{References}

Aaker, D.A. (1991). Managing Brand Equity: Conceptualizing on the Value of a Brand. New York, NY: The Free Press. Aaker, D.A. (1992). The value of brand equity.Journal of Business Strategy, 13(4), 85-104.

Aaker, D.A., \& Joachimsthaler, E. (2000). Brand Leadership. New York, NY: The Free Press.

Anderson, J., \& Gerbing, D. (1988). Structural equation modeling in practice: a review and recommended two-step approach. Psychological Bulletin, 13, 411-423.

Bagozzi, R., \& Yi, Y. (1988). On the evaluation of structural equation models.Journal of the Academy of Marketing Science, 16(1), 74-94.

Baumgarth, C. (2010). Living the brand: Brand orientation in the business-to-business sector. European Journal of Marketing, 44(5), 653-671.

Bentler, P. (2005). EQS 6 Structural Equations Program Manual. Encino, CA: Multivariate Software.

Berry, L.L. (2000). Cultivating service brand equity. Journal of the Academy of Marketing Science, 28(1), 128-137.

Berthon, P.R., Pitt, L., \& Campbell, C. (2008). Ad lib: When customers create the ad. California Management Review, $50(4), 6-31$.

Brakus, J.J., Schmitt, B.H., \& Zarantonello, L. (2009). Brand experience: What is it? How is it measured? Does affect loyalty? Journal of Marketing, 73(3), 52-68.

Brown, T. (2006). Confirmatory Factor Analysis for Applied Research. New York, NY: The Guilford Press.

Byrne, B. (2006). Structural Equation Modeling With EQS, Basic Concepts, Applications, and Programming. 2th Edition. London; LEA Publishers.

Chaudhuri, A., \& Holbrook, M.B. (2001). The chain of effects form brand trust and brand affect to brand performance: The role of brand loyalty. Journal of Marketing, 65(2), 81-93.

Feldwick, P. (1996). What id brand equity anyway, and how you measure it? Journal of the Market Research Society, 38(2), 85-104.

Fornell, C., \& Larcker, D. (1981). Evaluating structural equation models with unobservable variables and measurement error. Journal of Marketing Research, 18, 39-50.

Fournier, S. (1998). Consumers end their brands: Developing relationship theory in consumer research. Journal of Consumer Research, 24(4), 343-353.

Hair, J.F., Anderson, R.E., Tatham, R.L., \& Black, W.C. (1995).Multivariate Data Analysis with Readings. New York, NY: Prentice-Hall.

Hatcher, L. (1994).A Step by Step Approach to Using the SAS System for Factor Analysis and Structural Equation Modeling, Cary, NC: SAS Institute Inc.

Hirschman, E.C., \& Holbrook, M.B. (1982). Hedonic consumption: Emerging concepts, methods and propositions. Journal of Marketing, 46(3), 92-101.

Holbrook, M.B., \& Hirschman, E.C. (1982). The experiential aspects of consumption: Consumer fantasies, feelings, and fun. Journal of Consumer Research, 9(2), 132-140.

Jeon, J.E. (2017). The impact of brand concept on brand equity.Asia Pacific Journal of Innovation and Entrepreneurship, 11(2), 233-245.

Jeon, J.E., \& Lee, J. (2016). Brand schematicity moderates the effects of aesthetics brands on brand accessories purchase intentions. Social Behavior and Personality, 44(10), 1733-1746.

Kapferer, J.N. (2004). The New Strategic Brand Management: Creating and Sustaining Brand Equity Long Term. London: Kogan Page.

Keller, K.L. (1993). Conceptualizing, measuring, and managing customer-based brand equity.Journal of Marketing, $57(1), 1-22$.

Keller, K.L. (2008). Strategic Brand Management: Building, Measuring, and Managing Brand Equity. $3^{\text {rd }}$ Edition. Upper Saddle River, NJ: Pearson Prentice-Hall.

Kotler, P., \& Armstrong, G. (2010). Principles of Marketing. Upper Saddler River, NJ: Pearson Education.

Krishna, A., Elder, R., \& Caldara, C. (2010). Feminine to smell but masculine to touch?Multisensory congruence and its effect on the aesthetic experience.Journal of Consumer Psychology, 21(3), 410-418.

M'zungu, S.D.M., Merrilees, B., \& Miller, D. (2010). Brand management to protect brand equity: A conceptual model. Brand Management Journal, 17(8), 605-617.

Malär, L., Krohmer, H., Hoyer, W.D., \&Nyffenegger, B. (2011). Emotional brand attachment and brand personality: The relative importance of the actual and the ideal self. Journal of Marketing, 75(4), 35-52.

McCracken, G.D. (1990). Culture and Consumption: New Approaches to the Symbolic Character of Consumer Goods and Activities. Bloomington: Indiana University Press. 
Morgan, R.M., \& Hunt, S.D. (1994). The commitment-trust theory of relationship marketing.Journal of Marketing, 58(3), 20-38.

Nunally, J.C., \& Bernstein, I.H. (1994). Psychometric Theory. $3^{\text {a }}$ Edition. New York, NY: McGraw-Hill.

Oliver, R.L. (1999). Whence consumer loyalty? Journal of Marketing, 63(4), 33-44.

Park, C.W., Eisingerich, A.B., Pol, G., \& Park, J.W. (2013). The role of brand logos in firm performance.Journal of Business Research, 66(2), 180-187.

Park, C.W., Jaworski, B.J., \&MacInnis, D.J. (1986). Strategic brand concept-image management.Journal of Marketing, 50(4), 135-145.

Park, C.W., MacInnis, D.J., Priester, J., Eisingerich, A.B., \&Iacobucci, D. (2010). Brand attachment and brand attitude strength: Conceptual and empirical differentiation of two critical brand equity drivers. Journal of Marketing, 74(6), 1-17.

Srivastava, R.K., Shervani, T.A., \& Fahey, L. (1998). Market-based assets and shareholder value: A framework for analysis. Journal of Marketing, 62(1), 2-18. 